\title{
ANALISIS DAN PERANCANGAN \\ SISTEM INFORMASI EKSEKUTIF PEMASARAN \\ PADA DISTRIBUTOR ALAT TULIS KANTOR: STUDI KASUS PADA BENZA PRIMA
}

\author{
Mohammad Subekti; Raden Bagus Rhesa Dharma Widjaya; \\ Eileen Heriyanni; Giovani Dewi
}

\author{
Computer Science Department, School of Computer Science Binus University \\ Jl. K.H. Syahdan No. 9, Palmerah, Jakarta Barat 11480 \\ subekti@binus.ac.id
}

\begin{abstract}
Executive information system (EIS) has been widely used in enterprises and institutions to help the executives make decisions quickly and accurately for the organization's business needs. A research is conducted to create a marketing executive information system that can produce analytic reports and comparison reports for the executive of Benza Prima. For information search the fact finding techniques is utilized by conducting surveys directly to the company to study the company needs and the running procedures. The executive information system design uses Object Oriented Analysis and Design (OOAD) methodology. The research results in an executive information system that produces report in forms of pivot tables and charts to help the Benza Prima executives make decisions. The marketing executive information system design is expected to provide analytic information that can be used by the Benza Prima executive as an analytic tool in planning marketing strategies.
\end{abstract}

Keywords: executive information system, marketing analysis, analytic reports, Object Oriented Analysis and Design

\begin{abstract}
ABSTRAK
Sistem informasi eksekutif (SIE) telah banyak digunakan dalam perusahaan dan institusi untuk membantu para eksekutif mengambil keputusan secara cepat dan akurat bagi kebutuhan bisnis organisasi. Untuk membuat sebuah sistem informasi eksekutif pemasaran bagi eksekutif Benza Prima sebuah penelitian dilakukan. Sistem informasi eksekutif pemasaran dirancang dapat menghasilkan laporan yang bersifat analitik dan laporan perbandingan dalam bentuk pivot tabel dan grafik untuk analisis pemasaran. Fact finding techniques digunakan untuk mencari informasi dengan melakukan survei langsung ke perusahaan untuk mempelajari kebutuhan perusahaan dan prosedur berjalan. Perancangan sistem informasi eksekutif menggunakan metode Object Oriented Analysis and Design (OOAD). Penelitian ini menghasilkan suatu laporan bagi eksekutif Benza Prima dalam bentuk pivot tabel dan grafik yang dapat membantu eksekutif melakukan pengambilan keputusan. Sistem informasi eksekutif pemasaran yang dirancang diharapkan dapat memberikan informasi analitik kepada eksekutif Benza Prima dalam melakukan perencanaan strategi pemasaran.
\end{abstract}

Kata kunci: sistem informasi eksekutif, analisis pemasaran, laporan analitik, Object Oriented Analysis and Design 


\section{PENDAHULUAN}

Sistem informasi eksekutif (SIE) merupakan sistem informasi yang telah banyak digunakan dalam perusahaan dan institusi. Sistem informasi eksekutif dapat membantu para eksekutif dalam mengambil keputusan untuk kebutuhan bisnis organisasi secara tepat, akurat, dan cepat sesuai dengan fakta dan data yang ada. Sistem informasi eksekutif mampu menyimpan data dan menyajikannya kembali menjadi informasi summary yang dapat dibuat detil oleh eksekutif.

Menurut McLeod \& George (2008, p.245), sistem informasi eksekutif (executive information system) adalah suatu sistem yang memberikan informasi kepada para manajer di tingkat yang lebih tinggi atas kinerja perusahaan secara keseluruhan. Sedangkan Menurut O’Brien (2006, p457), Executive Information System (EIS) adalah sistem informasi yang menggabungkan berbagai fitur sistem informasi manajemen dan sistem pendukung keputusan untuk menyediakan akses informasi yang mudah dan cepat kepada eksekutif tingkat atas mengenai faktor-faktor penentu keberhasilan (critical success factors-CSF) perusahaan.

Konfigurasi sistem informasi eksekutif yang berbasis komputer biasanya meliputi satu komputer personal. Pada perusahaan besar PC tersebut akan dihubungkan dengan sebuah mainframe. Komputer personal eksekutif tersebut berfungsi sebagai executive workstation. Konfigurasi perangkat kerasnya mencakup penyimpanan sekunder, kebanyakan dalam bentuk hard disk, yang menyimpan database eksekutif. Database eksekutif berisi data dan informasi yang telah diproses sebelumnya oleh komputer sentral perusahaan. Eksekutif memilih dari menu untuk menghasilkan tampilan layar yang telah disusun sebelumnya (preformatted), atau untuk melakukan sejumlah kecil pemrosesan. Sistem itu juga memungkinkan pemakai menggunakan sistem pos elektronik perusahaan dan mengakses data dan informasi lingkungan. Dalam beberapa kasus, personil pendukung SIE memasukan berita terbaru dan penjelasan mengenai informasi yang berkaitan. Peran utama SIE adalah membuat sintesis, atau melakukan pencarian data dan informasi bervolume besar untuk meningkatkan kegunaannya. Pengambilan sari ini disebut pemampatan informasi (information compression), dan menghasilkan suatu gambaran atau model mental dari operasi perusahaan.

Dalam membangun sistem informasi eksekutif, para eksekutif menggunakan beberapa konsep dasar yang bertujuan memungkinkan para eksekutif dapat memantau seberapa baiknya kinerja perusahaan dalam mencapai tujuannya. Konsep dasar tersebut terbagi atas tiga hal. Pertama yaitu faktor penentu keberhasilan atau critical success factor (CSF). Ini merupakan faktor yang paling penting dalam menyukseskan sebuah organisasi sebagai penentu keberhasilan atau kegagalan dalam segala jenis kegiatan suatu organisasi. Faktor-faktor ini berbeda dalam setiap perusahaan, tergantung dari kegiatan yang dilakukan. Yang kedua adalah management by exception (MBE). Perangkat lunak SIE yang akan digunakan oleh eksekutif akan menyajikan management by exception, dimana akan ditampilkan perbandingan antara kinerja yang direncanakan dengan kinerja aktual. Perangkat lunak SIE dapat mengidentifikasi perkecualian-perkecualian secara otomatis dan membuatnya diperhatikan oleh eksekutif, sehingga informasi dapat digunakan untuk menyelesaikan setiap permasalahan yang terjadi. Dan yang ketiga dalah model mental. Peran utama sistem informasi eksekutif adalah membuat sari dari data dan informasi yang volumenya besar untuk meningkatkan kegunaannya. Pengambilan sari ini disebut pemampatan informasi (information compression), yang menghasilkan suatu gambaran atau model mental dari operasi perusahaan. Model tersebut memungkinkan seseorang membuat penilaian dan perkiraan untuk memahami, memutuskan tindakan yang perlu diambil dan untuk mengembalikan pelaksanaannya.

Beberapa karakteristik sistem informasi eksekutif menurut Turban dan Aronson (2005, p.417422), antara lain: (1) drill down - salah satu kemampuan sistem informasi eksekutif yang sangat berguna adalah menyediakan rincian atas informasi yang diberikan. Informasi yang diberikan kepada 
eksekutif melalui sistem informasi eksekutif akan berupa sebuah rangkuman dimana informasi itu sudah tersaji dalam bentuk rangkuman. Dengan teknik ini, eksekutif dapat secara bertahap mendapatkan informasi yang lebih rinci dari informasi yang terangkum tersebut, sesuai dengan kebutuhannya; (2) critical success factors (CSF), yaitu faktor yang harus diperhatikan dalam mencapai tujuan-tujuan organisasi. Faktor tersebut berbeda-beda dalam tiap-tiap perusahaan. Faktor-faktor ini dapat bersifat strategik, manajerial, atau operasional, dan berasal dari tiga sumber, yaitu: organisasi, industri, dan lingkungan; (3) status access - pada fitur ini data-data terakhir atau laporan pada status indikator kunci dapat diakses setiap saat melalui jaringan yang tersedia. Hubungan dari informasi adalah sangat penting dan penekanannya ditempatkan pada data yang ada sekarang; (4) analysis kemampuan yang dimiliki oleh sistem informasi eksekutif lainnya adalah analysis. Selain dapat melakukan akses terhadap data yang ada, para eksekutif juga dapat menggunakan sistem informasi eksekutif untuk melakukan analisis terhadap hasil informasi yang diinginkan, seperti memilih isi dari database, output dari analisis, dan bentuk penyajian informasi yang diinginkan; (5) exception reporting - exception reporting didasari pada konsep management by exception. Menurut konsep ini, eksekutif harus lebih memperhatikan penyimpangan yang terjadi terhadap standar yang ada. Demikian juga, dalam exception reporting perhatian eksekutif hanya akan dipanggil jika ada kasus dimana suatu performa sangat buruk atau sangat baik. Pendekatan ini akan menghemat waktu yang dibutuhkan bagi pembuat dan pembaca sebuah laporan; (6) use of coloring and audio - pemberian warna dan audio pada sistem informasi eksekutif dapat membantu dalam menentukan suatu kejadian yang dianggap penting. Hal ini dapat membantu eksekutif pada waktu menggunakan sistem informasi eksekutif. Salah satu contohmnya adalah penggunaan warna dapat digunakan untuk menandai penjualan tertinggi; (7) navigation of information - kemampuan sistem informasi eksekutif untuk memeriksa data dalam jumlah yang besar dengan cepat dan mudah; (8) communication - diperlukannya komunikasi dengan pihak lain oleh para eksekutif. Komunikasi tersebut dapat melalui email, yang dapat digunakan untuk mengirim kaporan kepada orang lain, panggilan untuk pertemuan, atau pemberitaan komentar melalui internet. Misalnya dengan menggunakan video teleconferencing.

Turban dan Aronson (2001, p.307) menyatakan beberapa faktor mempengaruhi penggunaan sistem informasi eksekutif, seperti: (1) faktor internal, yaitu kebutuhan akan informasi yang teratur, kebutuhan akan peningkatan informasi, kebutuhan pengaksesan terhadap data operasional, kebutuhan untuk pembaharuan aktivitas-aktivitas yang berbeda dalam waktu yang cepat, kebutuhan untuk mengidentifikasi tendensi perkembangan; (2) faktor eksternal, yaitu persaingan yang meningkat, perubahan lingkungan yang cepat, kebutuhan untuk menjadi produktif, kebutuhan untuk mengakses database eksternal, dan makin bertambahnya peraturan pemerintah.

Untuk mencapai sistem informasi eksekutif yang berhasil, Rockhart dan DeLong melakukan identifikasi pada delapan faktor penentu (McLeod \& George, 2004, p.361-362). Faktor-faktor tersebut adalah sebagai berikut: (1) sponsor eksekutif yang mengerti dan berkomitmen - eksekutif tingkat puncak, lebih dikenal dengan CEO, harus berfungsi sebagai sponsor eksekutif SIE dengan mendorong penerapannya. Usaha SIE yang paling berhasil adalah yang pemakai pertamanya adalah eksekutif puncak; (2) sponsor operasi - sponsor eksekutif kemungkinan besar terlalu sibuk untuk mencurahkan banyak waktu untuk penerapan. Tugas itu harus diberikan kepada eksekutif tingkat puncak lain, seperti wakil presiden eksekutif. Sponsor operasi bekerja sama dengan eksekuitf pemakai dan spesialis informasi untuk memastikan bahwa pekerjaan itu terlaksana; (3) staf jasa informasi yang sesuai harus tersedia spesialis informasi yang tidak saja mengerti teknologi informasi tetapi juga mengerti cara eksekutif menggunakan sistem itu. Area teknologi informasi yang dapat diterapkan meliputi komunikasi data, database, dan graphical user interface; (4) teknologi informasi yang sesuai - para penerap EIS seharusnya tidak berlebihan dan memasukan perangkat keras atau perangkat lunak yang tidak perlu. Sistem itu harus sesederhana mungkin dan harus memberikan tepat seperti yang eksekutif inginkan tidak lebih dan tidak kurang; (5) manajemen data - tidak cukup hanya menampilkan atau informasi. Eksekutif harus mengetahui seberapa mutakhir data itu. Ini dapat dicapai dengan mengidentifikasi tanggalnya dan idealnya, jam data itu dimasukan kedalam sistem. Eksekutif juga harus mampu mengikuti analisis data. Analisis ini dapat dicapai melalui drill down, dengan bertanya 
kepada manager data atau keduanya; (6) kaitan yang jelas dengan tujuan bisnis - sebagian besar SIE yang berhasil dirancang untuk memecahkan masalah-masalah sepesifik atau memenuhi kebutuhan yang ditangani oleh teknologi informasi; (7) manajemen atas penolakan organisasi - jika seorang eksekutif menolak SIE, perlu dilakukan upaya untuk mendapatkan dukungan. Strategi yang baik adalah mengidentifikasi satu masalah tunggal yang dihadapi eksekutif itu dan kemudian segera menerapkan SIE, dengan menggunakan prototyping, untuk mengatasi masalah tersebut. Perlu berhatihati dalam memilih masalah yang akan memungkinakn SIE Nampak baik. Kemudian, aplikasi tambahan dapat ditambahkan; (8) manajemen atas penyebaran dan evolusi system - pengalaman menunjukan bahwa jika manajemen tingkat atas mulai menerima informasi dari SIE, manajer tingkat bawah ingin menerima output yang sama. Manajer tingkat bawah ingin mampu mengantisipasi masalah dan memecahkannya sebelum manajer tingkat atas menganggap situasinya tak terkendali. Karena itu, SIE mengikuti pola trickle-down. Namun, perlu berhati-hati dalam menambah pemakai, yaitu hanya jika mereka bisa mendapatkan perhatian yang mereka perlukan. Salah satu alasan keberhasilan konsep SIE adalah tingkat pendidikan dan pelatihan pemakai yang tinggi.

Benza Prima yang merupakan salah satu perusahaan distribusi terkemuka yang bergerak dalam pendistribusian alat tulis kantor. Seiring dengan pesatnya pertumbuhan ekonomi, peningkatan permintaan pasar dan banyaknya perusahaan-perusahaan lain bermunculan yang juga bergerak di bidang alat tulis kantor di kota Semarang, diperlukan adanya suatu sistem informasi yang membantu eksekutif dalam menganalisis sektor pemasaran agar perusahaan tetap bisa bertahan di tengah persaingan bisnis yang semakin ketat.

Oleh karena itu untuk menghasilkan informasi yang khusus diperuntukkan bagi para eksekutif pada perusahaan Benza Prima, diperlukan suatu sistem yang dirancang khusus untuk keperluan tersebut, yaitu sistem informasi eksekutif. Dengan sistem yang dirancang khusus diharapkan para eksekutif dapat memenuhi kebutuhan informasi yang diinginkan untuk mengambil keputusan dan menyusun strategi dalam menghadapi persaingan sehingga dapat memajukan dan mempertahankan kejayaan perusahaan.

Pembahasan untuk perancangan aplikasi sistem informasi eksekutif ini antara lain penyediaan informasi untuk sektor pemasaran pada Benza Prima, sehingga dapat membantu memberikan gambaran pada jangka waktu tertentu bagi para eksekutif dalam menyusun strategi pemasaran. Informasi yang akan disajikan kepada eksekutif meliputi beberapa analisis yang mendukung perencanaan strategi pemasaran seperti analisis dan evaluasi penjualan, analisis retur penjualan, dan analisis promosi. Selain itu, akan disajikan juga informasi-informasi eksternal yang terdiri dari informasi pesaing dan analisis pasar.

Adapun tujuan penelitian ini yaitu: (1) membantu eksekutif dalam mengidentifikasi masalah yang terjadi dalam bidang pemasaran sehingga dapat mengambil langkah yang sesuai dengan masalah yang terjadi; (2) menganalisis sistem informasi yang sedang berjalan dan kebutuhan para eksekutif, sehingga dapat diketahui informasi summary apa saja yang dibutuhkan oleh eksekutif dalam membuat perencanaan dan pengambilan keputusan. Analisis yang dilakukan di antaranya adalah analisis kebutuhan (requirement analysis), analisis CSF (Critical Success Factor), analisis SWOT (Strength, Weakness, Opportunity and Threat), dan analisis EFAS (External Factor Analysis Summary) serta IFAS (Internal Factor Analysis Summary); (3) merancang suatu sistem informasi yang terintegrasi dalam bentuk hasil analisis yang disajikan dalam bentuk tabel dan grafik sehingga eksekutif dapat dengan mudah mengakses dan menganalisis data dalam pengambilan keputusan.

Manfaat dari penelitian ini, yaitu dapat: (1) menyediakan informasi yang aktual sehingga eksekutif menjadi lebih responsif terhadap keadaan yang ada sekarang dan membantu dalam membuat perencanaan menjadi lebih baik; (2) membuat eksekutif lebih maksimal dalam membuat perencanaan, menganalisis dan memantau perkembangan perusahaan; (3) meningkatkan mutu pengambilan keputusan dalam menentukan dan membuat kebijakan yang berkaitan dengan produk, harga dan 
promosi. Dari tujuan dan manfaat disebutkan di atas, diharapkan sistem ini dapat menjadi alat bantu eksekutif di lingkungan perusahaan Benza Prima dalam rangka proses-proses pengambilan keputusan, dan secara tidak langsung akan dapat memberikan berbagai keuntungan kompetitif bagi perusahaan.

\section{METODE}

Penyusunan karya ilmiah ini menggunakan empat metode. Pertama yaitu pengumpulan data dengan melakukan studi pustaka sebagai bahan referensi yang mendukung dalam perancangan sistem. Informasi-informasi yang didapat dari studi pustaka berupa informasi maupun bahan-bahan pendukung yang berasal dari buku, artikel, e-journal dan informasi-informasi lain yang berasal dari situs-situs web yang berkaitan dengan topik skripsi untuk mengetahui dan memahami dasar teori mengenai sistem informasi eksekutif Pemasaran.

Kedua yaitu survei secara langsung dengan melakukan pengamatan dan peninjauan secara langsung terhadap objek yang diteliti dari perusahaan tersebut, khususnya pada divisi pemasaran untuk mengumpulkan data yang dibutuhkan dalam penelitian ini, dan wawancara secara langsung dengan pihak yang berkepentingan dalam perusahaan yang berkaitan untuk mengidentifikasi kebutuhan informasi yang dibutuhkan oleh eksekutif.

Metode ketiga adalah analisis data, yaitu analisis strategi pemasaran menggunakan analisis bauran pemasaran, analisis 5 kekuatan persaingan Porter, analisis CSF (critical success factor) dan analisis SWOT (strength, weakness, opportunity, threat).

Metode terakhir yaitu perancangan. Analisis dan perancangan sistem informasi eksekutif yang akan diusulkan menggunakan metode OOAD, yang terdiri dari tahapan problem domain analysis, application domain analysis, component design dan architecture design.

\section{HASIL DAN PEMBAHASAN}

\section{Analisis Sistem yang Sedang Berjalan}

Secara umum, proses bisnis yang sedang berjalan pada Benza Prima adalah sebagai berikut: Proses pemesanan barang oleh customer kepada Benza Prima dapat dilakukan melalui telepon, email, dan faximile yang akan dilayani oleh bagian sales \& promotion (1). Setelah melakukan konfirmasi pesanan dan customer setuju dengan batas waktu pembayaran yang diberikan oleh Benza Prima, staf sales akan membuat SO (Sales Order) rangkap satu (2). SO asli akan diserahkan ke bagian cashier (2a) dan rangkap kedua akan diserahkan ke bagian accounting sebagai arsip perusahaan (2b).

Berdasarkan Sales Order yang diterima, bagian cashier akan membuat Faktur dan Surat Perintah Pengiriman Barang. Faktur akan dibuat rangkap dua, dimana faktur asli akan disimpan oleh cashier hingga faktur tersebut telah dilunasi oleh customer, rangkap pertama akan diberikan kepada inventory (3a) dan rangkap kedua akan diberikan kepada accounting sebagai arsip perusahaan (3b). Sedangkan Surat Perintah Pengiriman Barang akan dibuat rangkap satu, dimana rangkap dari surat tersebut akan diarsipkan dan surat yang asli akan diberikan kepada bagian inventory (3a). Setelah surat Faktur rangkap pertama dan Surat Perintah Pengiriman Barang diterima oleh bagian inventory (3). Bagian inventory akan membuat Surat Jalan (4) untuk dibawa bersama dengan surat Faktur rangkap pertama oleh bagian shipping (5) agar bagian shipping dapat mengirimkan barang ke customer. Sebelum dikirimkan kepada customer, barang tersebut akan dilakukan pengecekan terlebih dahulu 
oleh bagian inventory control. Selanjutnya, Surat Jalan asli yang telah di tandatangani oleh customer sebagai bukti pengiriman barang (6a) akan dibawa kembali oleh staf shipping untuk dikembalikan kepada bagian inventory (6b), sedangkan rangkapnya akan diarsipkan untuk perusahaan. Kemudian, Surat Jalan asli tersebut akan diberikan kepada bagian cashier (7).

Bagian cashier akan memberikan surat Faktur asli kepada bagian collector saat tanggal jatuh tempo untuk melakukan penagihan kepada customer (8). Collector bertugas melakukan penagihan kepada customer (9), dimana jangka waktu pembayaran bervariasi, tergantung pada kesepakatan dengan customer. Pada umumnya lama waktu pembayaran berkisar antara 30-45 hari dari tanggal faktur. Customer biasanya melakukan pembayaran melalui giro, cek atau transfer ke rekening perusahaan, dimana pembayaran dianggap lunas apabila dana tersebut sudah masuk ke dalam rekening perusahaan dan Faktur asli akan diberikan kepada pelanggan.

Apabila ada persediaan barang yang habis atau mulai menipis, bagian Inventory akan memberikan Laporan Persediaan Barang kepada bagian accounting untuk melakukan penambahan barang (10). Selanjutnya, bagian accounting akan memberikan Laporan Pemesanan Barang kepada bagian purchasing (11). Bagian purchasing akan membuat PO (Purchase Order) kepada supplier, dimana PO akan dibuat rangkap satu (12). PO yang asli akan diserahkan ke bagian accounting dan rangkap tersebut akan diarsipkan oleh bagian purchasing.

Proses penukaran atau pengembalian barang oleh customer akan dilayani oleh staf sales \& promotion (13). Setelah klaim retur diterima, bagian sales \& promotion akan memberikan laporan klaim retur tersebut ke bagian cashier (14). Selanjutnya, bagian cashier akan melakukan pengecekan terhadap produk yang akan di retur tersebut, apabila selisih jangka waktu penerimaan barang oleh customer dengan klaim retur kurang dari 14 hari dan jika keterangan klaim retur tersebut dapat diterima, retur tersebut dianggap valid. Selanjutnya, bagian cashier akan memberikan Surat Retur Barang yang akan dibuat menjadi rangkap dua untuk bagian inventory. Rangkap kesatu akan disimpan untuk arsip perusahaan, sedangkan Surat Retur Barang asli dan rangkap kedua akan diserahkan ke bagian inventory (15). Surat Retur Barang asli akan dibawa oleh bagian shipping dalam mengirimkan barang yang akan di retur tersebut (16). Sedangkan rangkap kedua akan disimpan oleh bagian inventory untuk diarsipkan. Kemudian Surat Retur Barang asli yang telah ditandatangai oleh customer akan dikembalikan ke bagian cashier sebagai arsip perusahaan. Gambar 2 merupakan Rich Picture dari sistem yang sedang berjalan pada Benza Prima.

\section{Analisis Strategi Pemasaran yang Sedang Berjalan}

Berdasarkan hasil analisis menggunakan matriks IFAS dan matriks EFAS dihasilkan nilai dari IFAS sebesar 2.83 dan nilai dari EFAS sebesar 2.43. Hal ini mengindikasikan bahwa Benza Prima berada pada posisi sel ke-5, yaitu growth dan stability. Strategi yang dapat digunakan adalah strategi pertumbuhan melalui integrasi horizontal, yaitu suatu kegiatan untuk memperluas perusahaan dengan cara membangun di lokasi lainnya yang memiliki potensi dan meningkatkan kualitas pelayanan jasa.

\section{Permasalahan yang Sedang Dihadapi}

Dalam Sistem Informasi Pemasaran pada Benza Prima terdapat beberapa masalah yang menjadi kendala bagi eksekutif dalam memenuhi kebutuhan informasi yang dibutuhkannya dan membuat perencanaan strategis dan pengambilan keputusan yang tepat. Masalah-masalah tersebut adalah: (1) laporan yang disajikan kepada eksekutif masih dalam bentuk print-out sehingga menghabiskan waktu untuk memeriksa, menyortir, menganalisis dan mengevaluasi laporan tersebut; (2) eksekutif mengalami kesulitan dalam melihat penjualan yang tertinggi dan terendah pada setiap periode penjualan; (3) sistem yang sedang berjalan belum dapat menampilkan informasi eksternal mengenai pesaing dan pasar sehingga eksekutif menjadi kesulitan dalam melihat secara tepat peluang pasar yang ada dan seberapa besar pangsa pasar yang telah dikuasai untuk dijadikan bahan 
perbandingan bagi perusahaan dalam memenuhi target penjualan; (4) sistem yang sedang berjalan belum dapat menyajikan laporan yang berisikan informasi mengenai exceptional report penjualan.

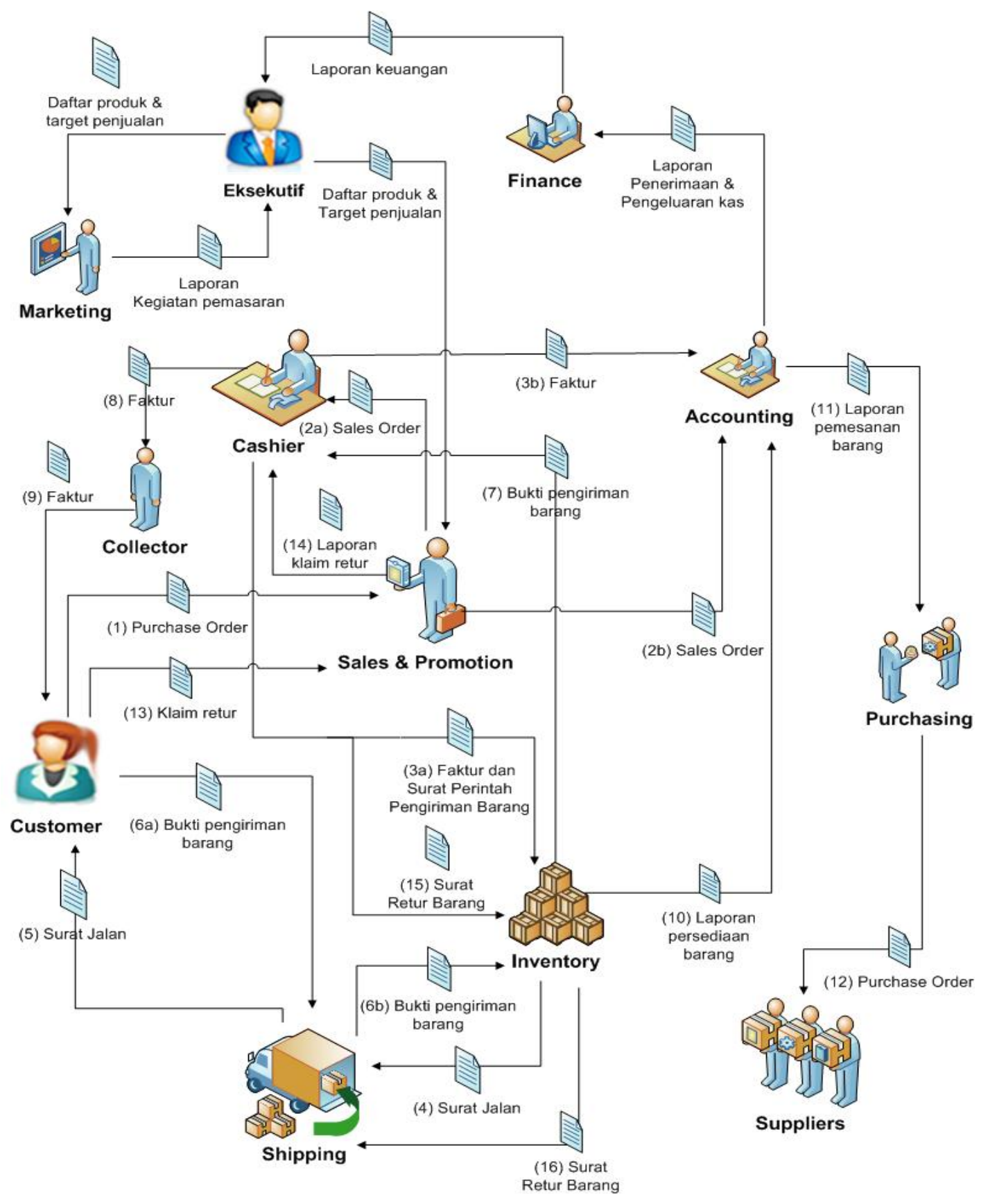

Gambar 2. Rich picture sistem berjalan.

\section{Usulan Pemecahan Masalah}

Untuk memecahkan masalah terhadap sistem yang sedang berjalan saat ini, diusulkan untuk dibangun suatu sistem informasi eksekutif pemasaran yang dapat memenuhi kebutuhan para Eksekutif dalam mengambil keputusan yang benar dan tepat waktu. Adapun kriteria sistem informasi eksekutif Pemasaran yang akan dirancang sebagai berikut: (1) menyajikan informasi atau laporan yang 
dibutuhkan eksekutif yang dilengkapi dengan tabel dan grafik menggunakan fasilitas drill down sehingga dapat memudahkan eksekutif dalam menganalisis dan memonitor informasi tentang pemasaran yang meliputi produk, harga, tempat dan promosi; (2) sistem yang dirancang dapat menyediakan informasi internal dan eksternal tentang pesaing dan analisis pangsa pasar sehingga membantu eksekutif dalam menganalisis situasi persaingan dan pangsa pasar yang telah dikuasai pesaing; (3) sistem yang akan dirancang ini juga akan menyajikan exceptional report untuk menampilkan informasi perbandingan antara yang tertinggi dengan yang terendah. Laporan-laporan penyimpangan ini disajikan dalam bentuk yang ringkas sehingga menghemat waktu kinerja eksekutif.

\section{Rancangan Sistem}

Sistem informasi eksekutif yang akan dirancang ini diharapkan dapat mencapai tujuannya, yaitu menghasilkan sebuah aplikasi yang mampu menyajikan informasi yang dibutuhkan oleh eksekutif Benza Prima secara dinamis, tepat waktu dan mudah untuk dipahami karena bersifat user friendly, sehingga mampu meningkatkan kemampuan eksekutif dalam perencanaan strategi dalam jangka waktu tertentu dan pengambilan keputusan yang tepat waktu.

Aplikasi sistem informasi eksekutif Pemasaran ini dirancang dengan dilengkapi fitur Drill Down dan Exceptional Report sehingga dapat memudahkan eksekutif dalam memperoleh informasi yang dibutuhkannya, khususnya informasi yang berhubungan dengan bauran pemasaran (4P), yaitu product, price, place dan promotion yang sesuai dengan CSF (Critical Success Factor), sehingga akan memudahkan eksekutif dalam melakukan perencanaan strategi pemasaran. Sistem informasi eksekutif Pemasaran ini akan menampilkan informasi tentang analisis penjualan, evaluasi penjualan, analisis retur penjualan, analisis promosi, analisis pesaing dan pangsa pasar. Dengan dirancangnya sistem informasi eksekutif Pemasaran ini diharapkan eksekutif dapat lebih mudah untuk memantau perkembangan pemasaran perusahaan baik internal maupun eksternal yang mendukung pengambilan keputusan-keputusan strategis yang berkaitan dengan pemasaran.

\section{Faktor Kriteria Sistem}

Pada bagian ini akan dijelaskan beberapa faktor kriteria sistem yang akan dibangun adalah sebagai berikut: (1) functionality - menyajikan informasi yang dibutuhkan oleh eksekutif sehingga dapat mempermudah eksekutif dalam memperoleh informasi mengenai perkembangan pemasaran perusahaan baik secara internal maupun eksternal agar dapat membuat perencanaan strategis yang tepat dari informasi yang dimiliki; (2) application - sistem informasi eksekutif pemasaran ini meliputi analisis penjualan, evalusi penjualan, analisis retur penjualan, analisis promosi, analisis produk penjualan pesaing dan analisis pangsa pasar; (3) condition - sistem ini dapat menyajikan fasilitas akses informasi pemasaran bagi eksekutif secara dinamis, tepat waktu, dan user friendly; (4) technology menggunakan seperangkat PC yang mendukung aplikasi sistem berupa Visual Basic.Net, DevExpress 9.2.4 dan database yang menggunakan Microsoft SQL Server 2005, serta pembuatan laporan menggunakan Crystal Report; (5) Objects MUser, PenjualanPesaing, Pesaing, Wilayah, Pelanggan, SalesOrder, SalesOrder_Detail, Produk, Supplier, KategoriProduk, TargetPenjualan, Penjualan_Detail, Penjualan; (6) responsibility - sebagai tool yang dapat mempermudah eksekutif dalam mengakses informasi untuk memantau perkembangan pemasaran perusahaan.

\section{Struktur}

Structure mendefinisikan relasi struktural antara class dan object pada problem domain. Hasil dari menentukan structure adalah class diagram berikut (Gambar 3). 


\section{Use Case Diagram}

Use Case diagram adalah gambaran fungsionalitas dari suatu sistem, sehingga eksekutif atau pengguna sistem paham dan mengerti mengenai kegunaan sistem yang akan dibangun. Gambar 4 berikut adalah use case diagram untuk sistem informasi eksekutif Pemasaran pada Benza Prima, Semarang.

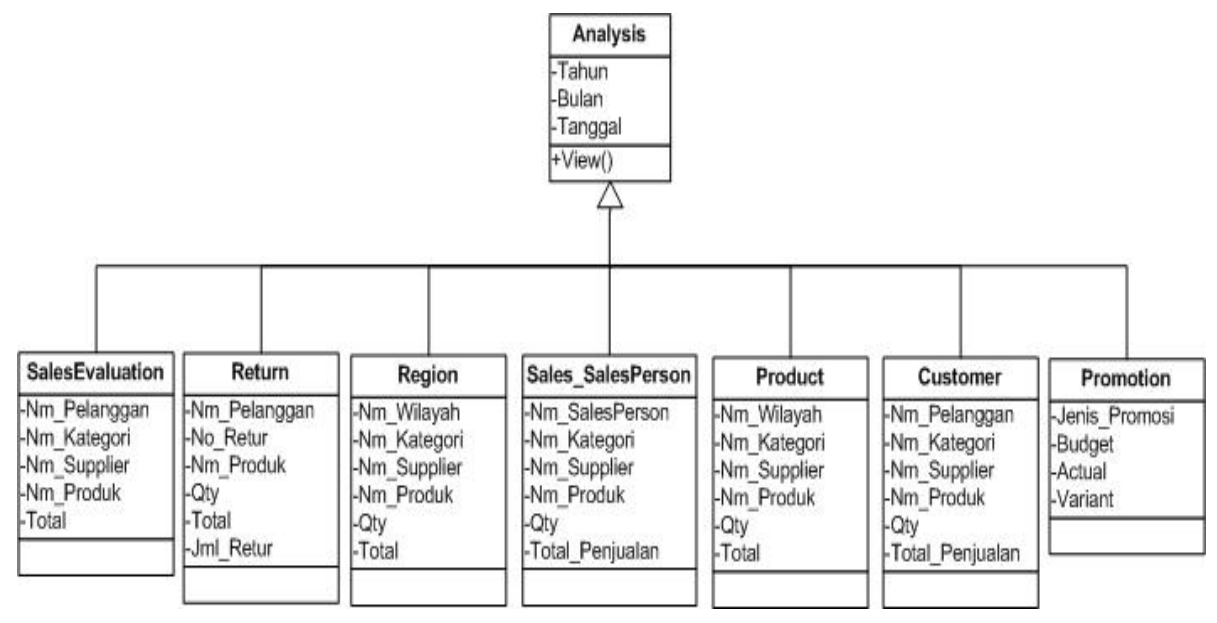

Gambar 3. Generalization analysis.

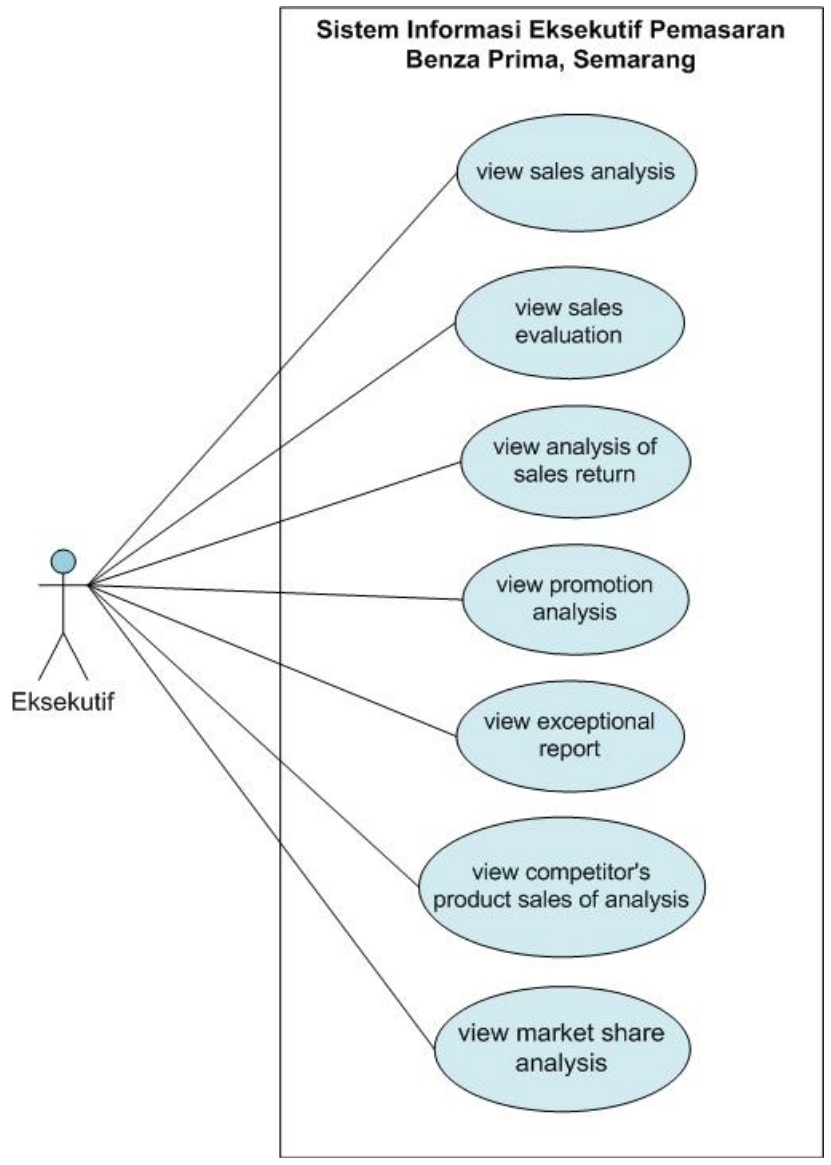

Gambar 4. Use case diagram. 


\section{Class Diagram}

Untuk mendukung proses-proses yang baru maka diperlukan perancangan ulang pada basisdata yang ada, seperti yang digambarkan strukturnya pada Gambar 5 di bawah ini.

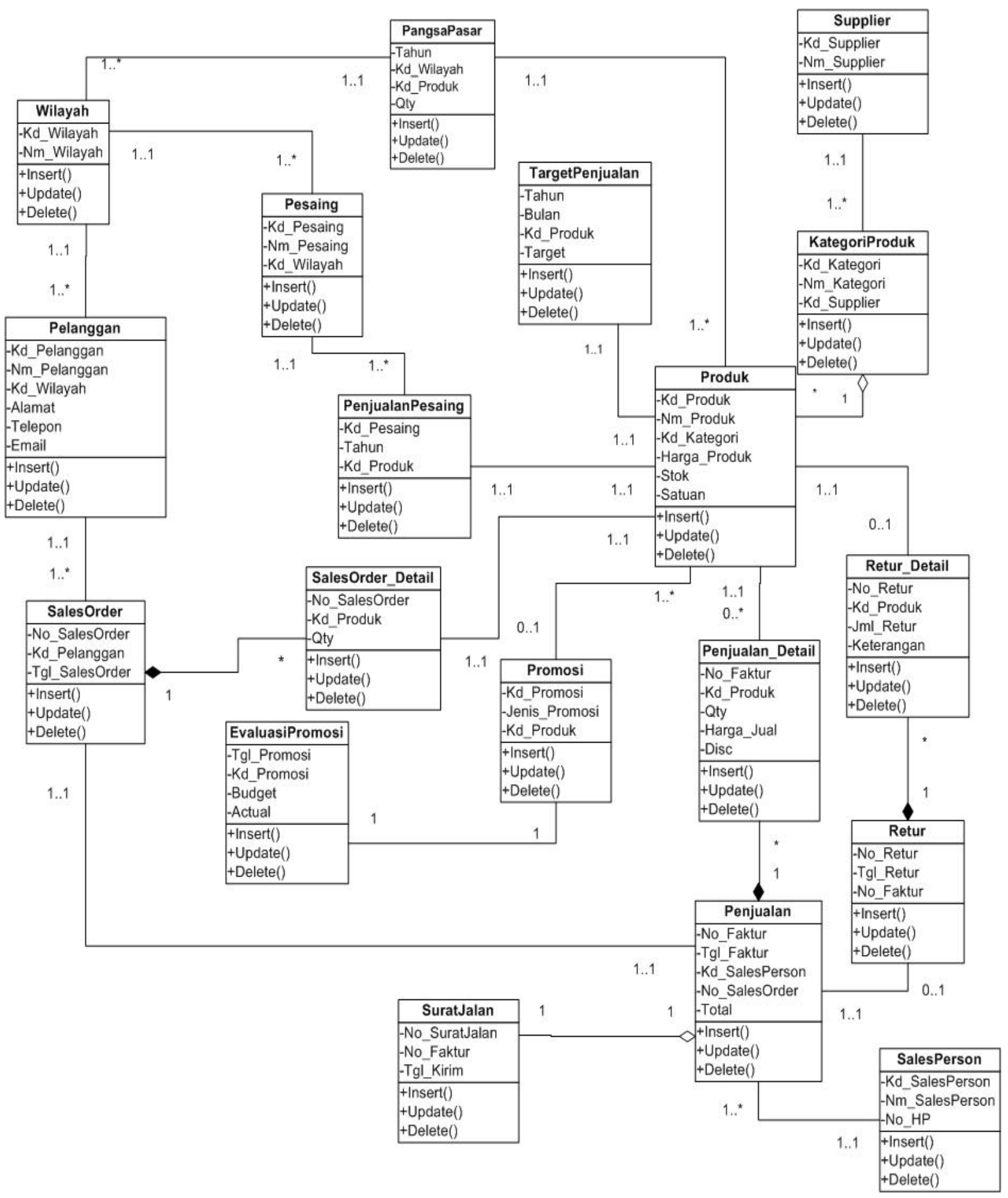

Gambar 5. Revised class diagram. 


\section{Hasil Perancangan Sistem Eksekutif}

Berikut ini sistem informasi eksekutif pemasaran yang diusulkan: (1) sales akan memberikan data penjualan, retur barang, dan informasi promosi kepada bagian marketing; (2) bagian marketing secara rutin mencari informasi-informasi diluar perusahaan (external company), seperti informasi tentang para pesaing, serta produk-produk terbaru yang dicari oleh pelanggan; (3) bagian pemasaran mendapatkan informasi eksternal perusahaan yang dibutuhkan oleh perusahaan; (4) bagian pemasaran akan memasukkan/meng-entry data yang diperoleh ke dalam sistem; (5) setelah informasi yang dientri oleh bagian pemasaran, sistem akan meng-update informasi tersebut ke dalam server SIE pemasaran untuk diolah; (6) eksekutif akan membuka menu yang ada pada aplikasi SIE pemasaran untuk melihat dan memperoleh informasi yang sedang dibutuhkan; (7) sistem akan mencari informasi yang diinginkan oleh eksekutif ke dalam server SIE Pemasaran. Hasil pencarian informasi tersebut akan ditampilkan untuk dilihat oleh eksekutif. dalam berbagai bentuk query sebagai berikut: Analysis of Sales by Product Query, Analysis of Sales by Sales Person Query, Analysis of Sales by Customer Query, Analysis of Sales by Region Query, Analysis of Sales by Target Query, Sales Evaluation Query, Analysis of Sales Return Query, Promotion Analysis Query, Competitor's Product Sales Analysis Query, Market Share Analysis Query, Fast Moving Sales Query, Slow Moving Sales Query. Gambar 6 berikut ini merupakan rich picture sistem yang dibangun pada Benza Prima:

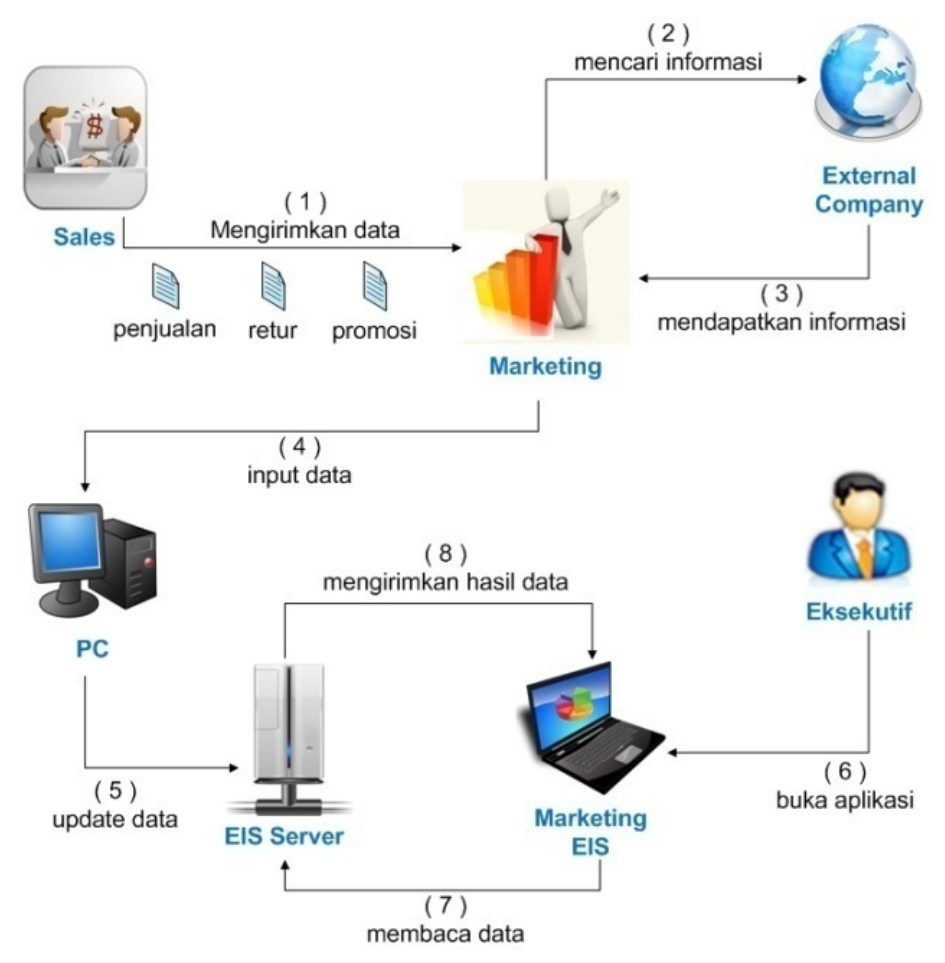

Gambar 6. Rich Picture sistem informasi eksekutif yang dibangun.

\section{Jadwal Implementasi}

Jadwal implementasi sistem merupakan suatu rencana yang berhubungan dengan waktu pengimplementasian sistem baru yang telah dirancang. Jadwal implementasi aplikasi sistem informasi eksekutif Pemasaran yang diusulkan pada Benza Prima diharapkan agar sistem yang baru dapat berjalan dengan baik dan memenuhi kebutuhan pihak eksekutif. Jadwal implementasi sistem informasi eksekutif Pemasaran pada Benza Prima adalah sebagai berikut: 
Tabel 1

Jadwal Implementasi

\begin{tabular}{|c|c|c|c|c|c|c|c|c|c|c|c|c|c|}
\hline \multirow{2}{*}{ No. } & \multirow{2}{*}{ Aktivitas } & \multicolumn{12}{|c|}{ Minggu Ke- } \\
\hline & & 1 & 2 & 3 & 4 & 5 & 6 & 7 & 8 & 9 & 10 & 11 & 12 \\
\hline 1 & Pembentukan tim & $\sqrt{ }$ & $\sqrt{ }$ & & & & & & & & & & \\
\hline 2 & Pengadaan Hardware dan Software & & $\sqrt{ }$ & $\sqrt{ }$ & & & & & & & & & \\
\hline 3 & Instalasi & & & & $\sqrt{ }$ & & & & & & & & \\
\hline 4 & Transformasi data ke dalam database & & & & & $\sqrt{ }$ & $\sqrt{ }$ & & & & & & \\
\hline 5 & Uji coba sistem yang baru & & & & & & $\sqrt{ }$ & $\sqrt{ }$ & $\sqrt{ }$ & & & & \\
\hline 6 & Pelatihan personil & & & & & & & & & $\sqrt{ }$ & $\sqrt{ }$ & & \\
\hline 7 & Evaluasi sistem yang baru & & & & & & & & & & & $\sqrt{ }$ & $\sqrt{ }$ \\
\hline 8 & Dokumentasi & $\sqrt{ }$ & $\sqrt{ }$ & $\sqrt{ }$ & $\sqrt{ }$ & $\sqrt{ }$ & $\sqrt{ }$ & $\sqrt{ }$ & $\sqrt{ }$ & $\sqrt{ }$ & $\sqrt{ }$ & $\sqrt{ }$ & $\sqrt{ }$ \\
\hline
\end{tabular}

\section{PENUTUP}

Berdasarkan hasil analisis lima kekuatan persaingan Porter pada Benza Prima, dapat disimpulkan sebagai berikut: (1) ancaman pendatang baru - walaupun potensi masuknya pendatang baru dapat dikatakan masih sangat kecil karena beberapa hambatan yang ada, Benza Prima tetap harus dapat menjaga pangsa pasar yang telah dikuasainya sejak lama, meningkatkan pangsa pasarnya, serta menciptakan strategi jangka pendek untuk menghalangi masuknya pendatang baru sesuai dengan perkembangan pasar yang tidak menentu; (2) Tingkat persaingan di antara pesaing yang ada - dengan ketatnya persaingan yang ada, Benza Prima harus cermat dalam memperhatikan strategi yang diterapkan oleh perusahaan lain. Jika tidak dapat melawan strategi yang digunakan oleh perusahaan lain, perusahaan dapat tersingkir dari persaingan yang sedang terjadi; (3) kekuatan tawar menawar pemasok - pemasok memiliki kekuatan tawar menawar yang relatif kecil karena pemasok tidak memonopoli semua produk yang tersedia pada Benza Prima, seperti untuk produk-produk dengan merek atau brand tertentu; (4) kekuatan tawar menawar pembeli - pangsa pasar dalam bisnis ini adalah agen-agen distributor dan pengecer atau toko-toko. Untuk agen-agen distributor atau grosir memiliki kekuatan tawar menawar pembeli yang sangat besar. Hal ini dikarenakan penjualan yang dapat dilakukan pada agen distributor/grosir sangatlah besar. Sedangkan untuk penjual eceran/tokotoko kekuatan tawar menawar pembeli tidak begitu besar. Untuk menghadapai kekuatan tawar menawar pembeli ini maka Benza Prima menerapkan strategi pemberian potongan harga untuk penjualan dengan kuantiti tertentu; (5) ancaman produk substitusi - berlakunya peraturan Asean Free Trade Area (AFTA) pada awal tahun 2010 dapat menguntungkan dan merugikan Benza Prima karena harga produk-produk buatan China yang memiliki harga yang relatif lebih murah akan bersaing dengan harga produk lokal, sehingga kekuatan tawar menawar pemasok terhadap perusahaan menjadi relatif lebih kecil. Namun, kondisi ini juga dapat merugikan Benza Prima karena akan ada banyak produk alat tulis kantor dengan harga yang lebih murah, sehingga persaingan harga antar pesaing akan menjadi semakin ketat.

Berdasarkan hasil penelitian menggunakan analisis Critical Success Factor (CSF) pada Benza Prima, didapatkan beberapa faktor yang menunjang seluruh keberhasilan serta menentukan berjalannya roda usaha Benza Prima, yaitu pelayanan yang baik kepada pelanggan sebagai wujud komitmen perusahaan dalam menjaga kepercayaan dari pelanggan, harga yang ditawarkan kepada pelanggan merupakan harga bersaing terbaik yang dapat dijangkau oleh masyarakat, pengontrolan yang baik pada tingkat persediaan barang, dan promosi melalui media cetak maupun elektronik yang cukup efektif. 
Berdasarkan hasil analisis menggunakan matriks IFAS dan matriks EFAS dihasilkan nilai dari IFAS sebesar 2.83 dan nilai dari EFAS sebesar 2.43. Hal ini mengindikasikan bahwa Benza Prima berada pada posisi sel ke-5, yaitu growth dan stability. Strategi yang dapat digunakan adalah strategi pertumbuhan melalui integrasi horizontal, yaitu suatu kegiatan untuk memperluas perusahaan dengan cara membangun di lokasi lainnya yang memiliki potensi dan meningkatkan kualitas pelayanan jasa.

Agar rancangan sistem informasi eksekutif Pemasaran pada Benza Prima dapat berfungsi dengan baik dan berjalan sebagaimana mestinya serta dapat memenuhi harapan dan kebutuhan eksekutif Benza Prima, baik sekarang maupun di masa mendatang ada beberapa saran penting yang ingin disampaikan, antara lain: (1) mempertahankan dan meningkatkan kekuatan yang dimiliki Benza Prima saat ini serta memanfaatkan peluang yang ada dengan sebaik-baiknya. Selain itu, dengan kekuatan yang dimiliki oleh perusahaan diharapkan dapat meminimalkan pengaruh yang timbul dari kelemahan dan ancaman yang dihadapi oleh Benza Prima; (2) selain ditunjang oleh hardware dan software agar memadai, diperlukan juga sebuah tim pendukung SIE yang kompeten untuk menjaga dan memelihara sistem secara berkala; (3) hendaknya dilakukan update terhadap informasi eksternal secara periodik untuk periode tertentu dengan melakukan penelitian mengenai keadaan pesaing dan pasar yang selalu berubah sehingga perusahaan dapat mengantisipasi perubahan yang terjadi pada pasar dan pesaing; (4) hendaknya dilakukan pendokumentasian untuk setiap perubahan agar memudahkan pengembangan di masa depan.

\section{DAFTAR PUSTAKA}

McLeod Jr., R. \& George, S. (2004). Management Information Systems, $\left(9^{\text {th }}\right.$ ed.). New Jersey: Prentice Hall Inc.

McLeod Jr., R. \& George, S. (2008). Sistem Informasi Manajemen, (edisi ke-10, edisi Bahasa Indonesia). Jakarta: Penerbit Salemba Empat.

Turban, E., Aronson, J. E. (2005). Decision Support System and Intelligence Systems, (7 ${ }^{\text {th }}$ ed.). New Jersey: Prentice Hall Inc. 